\title{
Functional Evaluation of Sciatic Nerve Anastomosis Wraped by Freeze Dried Human Amniotic Membrane in Sprague Dawley Rat
}

\author{
Perdana Putra, $\mathrm{E}^{1}$, Utomo, $\mathrm{P}^{2}$, Idulhaq, $\mathrm{M}^{2}$
}

\author{
${ }^{1}$ Departement of Surgery, Faculty of Medicine, Baiturrahmah University, Padang, Indonesia \\ e-mail : ekopportho@gmail.com \\ ${ }^{2}$ Departement of Orthopaedic and Traumatology, Faculty of Medicine, Sebelas Maret University, Solo, \\ Indonesia
}

\begin{abstract}
Background. Peripheral nerve injury (PNI) is a common medical condition. The defected nerve, if not repaired as early as possible, can cause long-term denervation and neurotrophy failure for the target organ. This leads to a series of denervation manifestations, such as muscle atrophy, loss of sensory function, etc. and ultimately, these manifestations seriously affect the patient's sensorimotor function. ${ }^{1,2}$ Amniotic membranes have been widely used in ophthalmology and skin injury repair because of their anti-inflammatory properties. Objective: In this study, we measured therapeutic efficacy and determined if amniotic membranes could be used for sciatic nerve repair. Methods. A posttest only control group design has been done in 10 healthy Sprague Dawley rats. In all rats, a unilateral rightside sciatic nerve transection was performed and reanastomosed by different methods: Group I (control group): included 5 rats, the anastomosis was done by epineural microsutures wusing $8 / 0$ nylon. Group II: included 5 rats, the anastomosis was done by epineural microsutures using $8 / 0$ nylon and then wrapped by freeze dried human amniotic membrane. Functional evaluation of nerve recovery was done over 3 weeks postoperatively using walking tract analysis and calculate using Sciatic Functional Index. Result. Functional results showed that there was no significant difference of the sciatic functional index (SFI) between group I and group II. Conclusion. We can conclude that during 3 weeks functional evaluation, there is no significant difference between control group and experimental group that achieved freeze dried human amniotic membrane.
\end{abstract}

Keywords: sciatic nerve injury, freeze dried human amniotic membrane, walking tract analysis, sciatic functional index.

Abstrak

Latar Belakang. Cedera saraf tepi (PNI) adalah kondisi medis yang umum. Saraf yang cacat, jika tidak diperbaiki sedini mungkin, dapat menyebabkan denervasi jangka panjang dan kegagalan neurotrofi pada organ target. Hal ini menyebabkan serangkaian manifestasi denervasi, seperti atrofi otot, hilangnya fungsi sensorik, dll. Dan pada akhirnya, manifestasi ini sangat mempengaruhi fungsi sensorimotor pasien. 1,2 Membran ketuban telah banyak digunakan dalam oftalmologi dan perbaikan cedera kulit karena sifat anti-inflamasi mereka. Tujuan: Dalam penelitian ini, kami mengukur kemanjuran terapeutik dan menentukan apakah selaput ketuban dapat digunakan untuk perbaikan saraf skiatik. Metode. Disain kelompok kontrol posttest only telah dilakukan pada 10 ekor tikus Sprague Dawley sehat. Pada semua tikus, transeksi saraf skiatik sisi kanan unilateral dilakukan dan dilakukan kembali dengan metode yang berbeda: Kelompok I (kelompok kontrol): termasuk 5 tikus, anastomosis dilakukan dengan bedah mikro epineural menggunakan nilon 8/0. Kelompok II: terdiri dari 5 ekor tikus, dilakukan anastomosis dengan epineural microsutures menggunakan nilon 8/0 kemudian dibungkus dengan membran ketuban manusia yang telah dikeringkan. Evaluasi fungsional pemulihan saraf dilakukan selama 3 minggu pasca operasi menggunakan analisis saluran berjalan dan dihitung menggunakan Indeks Fungsional Siatik. Hasil fungsional menunjukkan bahwa tidak ada perbedaan yang signifikan indeks fungsional skiatik (SFI) antara kelompok I dan kelompok II. Kesimpulan. Dapat disimpulkan bahwa selama 3 minggu evaluasi fungsional, tidak ada perbedaan yang signifikan antara kelompok kontrol dan kelompok eksperimen yang mencapai ketuban kering beku.

Kata kunci: cedera saraf skiatik, selaput ketuban manusia yang beku, analisis saluran berjalan, indeks fungsional

skiatik. 


\section{INRODUCTION}

Peripheral nerve injuries (PNI) are common and have marked impact on the everyday life of the population at large. Thirty percent of these injuries arise from lacerations by sharp objects and long bone fractures, and in the remaining penetrating injuries, crush, ischemia, traction, electric shock and vibration play a role. Approximately 100000 patients undergo peripheral nerve surgery in the USA and Europe annually. ${ }^{3}$ Severe nerve injury has a devastating impact on patient's quality of life. $^{3}$

Synkinesis and axonal misrouting are the common complications after facial nerve repair or nerve anastomosis. Thus, it is essential to choose a suitable surgical modality to provide satisfactory results considering both aesthetics and functionality. The surgical modalities may be nerve grafts, regional muscle transfers, primary neurorrhaphy (anastomosis), free tissue transfers, static procedures, and nerve transfers. The gold standard technique is primary neurorrhaphy, but there is a long delay period between the injuries and repair. Nerve grafts, regional muscle transfers, and free tissue transfers are the preferred alternative techniques. ${ }^{4}$

Amniotic membrane (AM) may be a good candidate to solve this problem. The amniotic membrane is an avascular membrane that is composed of an epithelial layer and an inner mesodermal tissue, which can reduce potent proinflammatory cytokines. AM has been widely used in ocular reconstructions, wound care, etc. It has been used as fresh AM, dehydrated AM, and freeze-dried AM. Nakamura et al $(2014)^{5}$ concluded that the sterilized, freezedried AM retained most of the physical, biological, and morphologic characteristics of cryopreserved AM. ${ }^{5}$

This study will see the effect of freeze-dried amniotic membrane on nerve regeneration after anastomosis of sciatic nerve on Sprague dawley rat, based on functional evaluation using walking tract analysis.

\section{METHODS}

This is an experimental study, post test only control group design. This study was held at Klinik LPPT Gadjah Mada University on 1st - 22nd August 2015. Subject of the study was Sprague Dawley rat, male, 3 m.o, $250 \mathrm{~g}$ weight. Ten rats were divided into 2 groups; Group I (control group): right sciatic nerve was cut by surgical blade no 11, then anastomosed using monofilament nonabsorbable no 8/0; Group II (experimental group): right sciatic nerve was cut by surgical blade no 11, anastomosed using monofilament non-absorbable no $8 / 0$, and then wraped by freeze dried human amniotic membrane.

Walking track analysis (WTA) was used to evaluate the nerve regeneration on day $-1,7$, 14 , and 21. From data that was gained from WTA then we calculated the Sciatic functional index (SFI) using the formula:

SFI $=-38.3 \times \frac{\text { EPL-NPL }}{\text { NPL }}+109.5 \times \frac{\text { ETS-NTS }}{\text { NTS }}+13.3 \times \frac{\text { EIT-NIT }}{\text { NIT }}-8.8$

\section{RESULT}

All rat underwent walking track analysis at day $1,7,14$ and 21 . Both feet were smeared by ink and then placed on walking track box, as seen in the picture.

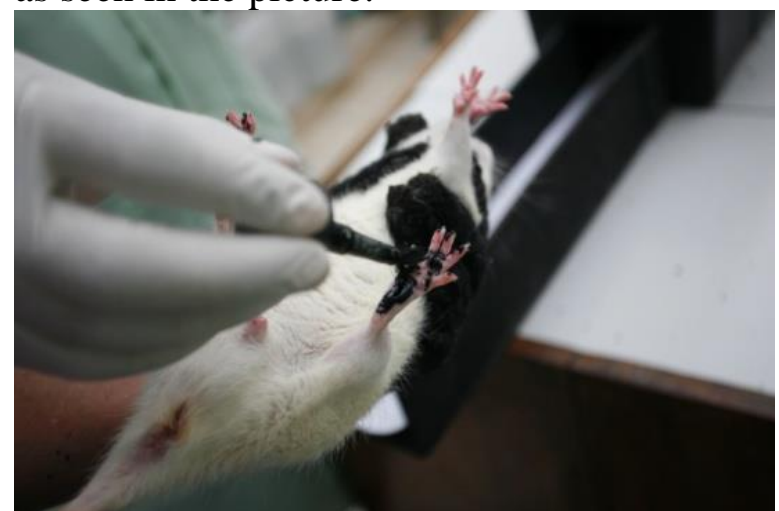

Figure 1. Both feet were smeared 


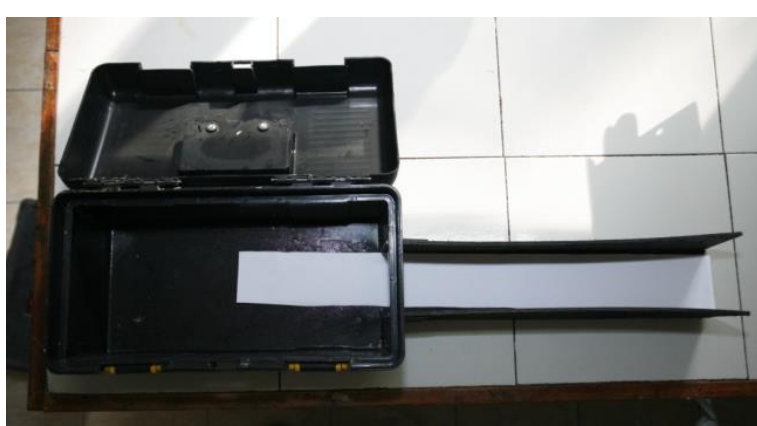

Figure 2. Walking track box

As the rat walk on the walking track box, the foot printed was gained as seen at the picture bellow.

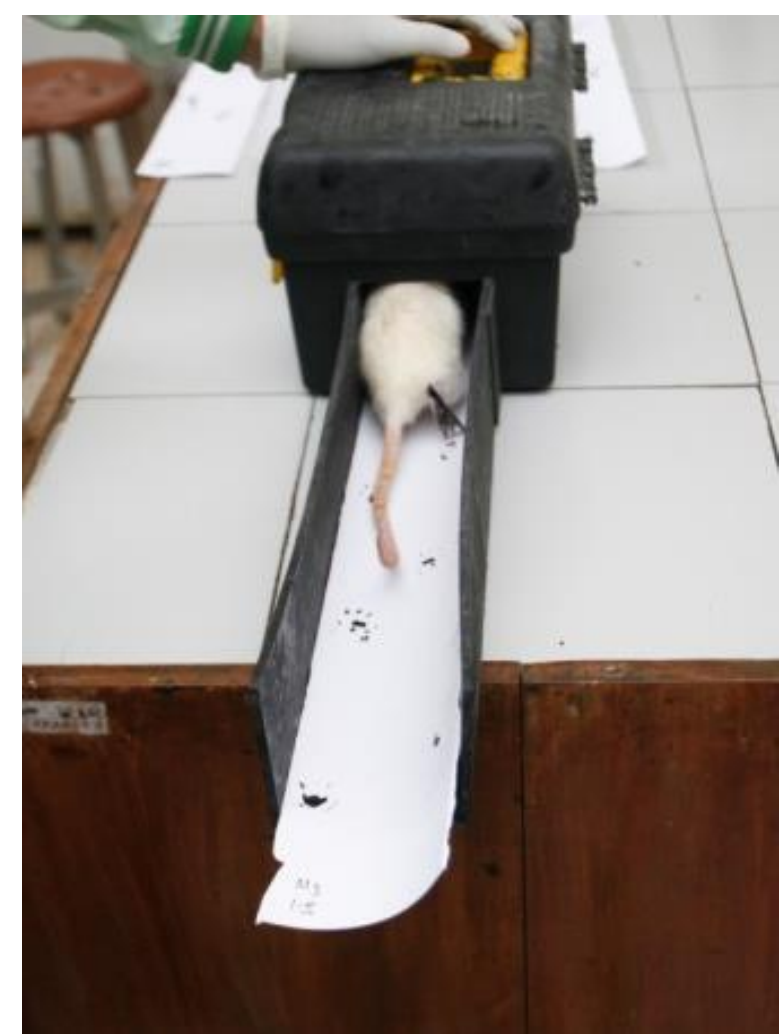

Figure 3. Foot print was gained as the rat walk on the walking track

Walking tract analysis was counted from the foot print that was gained at the walking track (Sarikcioglu et al. 2008) ${ }^{6}$ as seen in the picture bellow:
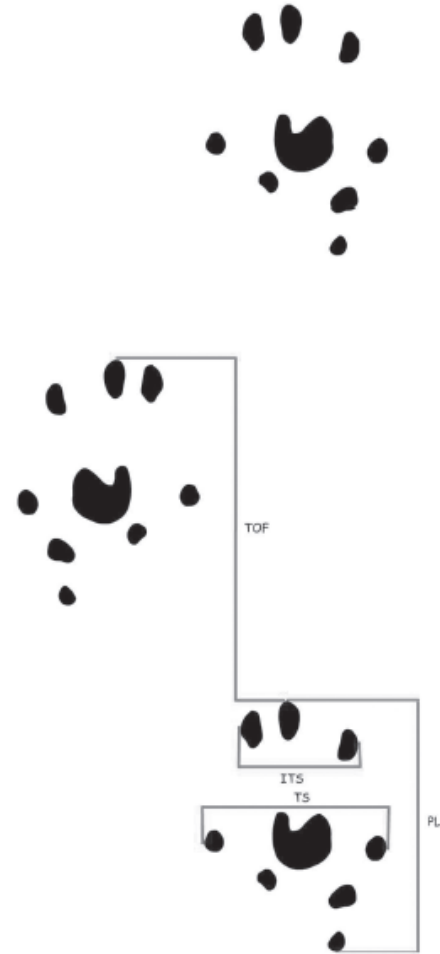

Figure 4. Walking Track Analysis; measurements are taken from the footprints; PL - distance from the heel to the third toe, the print length; TS — distance from the first to the fifth toe, the toe spread; ITS distance from the second to the fourth toe, the intermediate toe spread; TOF — distance to opposite foot.

The data that was gained from walking track analysis are presented on the following table below as mean of each day:

Table 1. Mean Of Walking Track Analysis Of Each Day For Each Group

\begin{tabular}{lllllllll}
\hline & \multicolumn{3}{c}{ Group I } & \multicolumn{5}{c}{ Gruop II } \\
\cline { 2 - 9 } & D1 & D7 & D14 & D21 & D1 & D7 & D14 & D21 \\
\hline EPL & 1 & 1 & 1 & 1 & 1 & 1 & 1 & 1 \\
NPL & 32 & 32 & 32 & 32 & 31 & 31 & 31 & 31 \\
ETS & 1 & 1 & 1 & 1 & 1 & 1 & 1 & 1 \\
NTS & 23 & 23 & 23 & 23 & 24 & 24 & 24 & 24 \\
EIT & 1 & 1 & 1 & 1 & 1 & 1 & 1 & 1 \\
NIT & 15 & 15 & 15 & 15 & 16 & 16 & 16 & 16 \\
TOF & 65 & 65 & 65 & 65 & 63 & 63 & 63 & 63 \\
\hline & & & & & & & &
\end{tabular}

Sciatic nerve functional index was calculated using the formula that has been explained previously. The results are presented on the following table below: 
Table 2. Sciatic Nerve Functional Index (SFI) Of Each Rat In Control (Group I) And Experimental (Group II) Group

\begin{tabular}{lllllllll}
\hline & \multicolumn{1}{c}{ Group I } & \multicolumn{7}{c}{ Group II } \\
\cline { 2 - 9 } Rat I & -88.91 & -88.91 & -88.91 & -88.91 & -88.90 & -88.90 & -88.90 & -88.90 \\
Rat II & -88.89 & -88.89 & -88.89 & -88.89 & -88.93 & -88.93 & -88.93 & -88.93 \\
Rat III & -88.90 & -88.90 & -88.90 & -88.90 & -88.91 & -88.91 & -88.91 & -88.91 \\
Rat IV & -88.92 & -88.92 & -88.92 & -88.92 & -88.92 & -88.92 & -88.92 & -88.92 \\
Rat V & -88.91 & -88.91 & -88.91 & -88.91 & -88.92 & -88.92 & -88.92 & -88.92 \\
Mean & -88.906 & -88.906 & -88.906 & -88.906 & -88.916 & -88.916 & -88.916 & -88.916 \\
\hline
\end{tabular}

An SFI of 0 indicates normal, and -100 indicates total impairment. However, de Medinaceli et al (1984) ${ }^{7}$ reported the normal values between +11 and -11 . At this study we found that the SFI of all rats are -88 , it indicates poor function. This value persists until day 21, as seen on the graphic bellow:

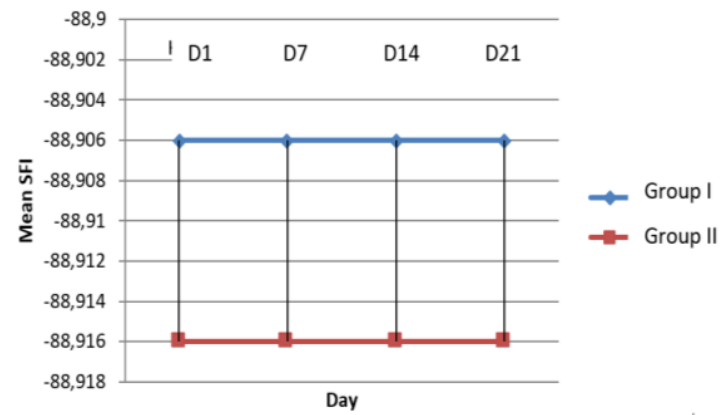

Graphic 1. Comparison of Average of SFI Group I and II on day $1,7,14$ and 21 .

From the graphic above we can see that there was no imporovement at all, the SFI persists at value of -88 until day 21 on both groups. T-Test result also shows there is no significant difference between control and experimental group for each day, as seen on the following table below:

Table 3. T-Test Result Of SFI Control And Experimental Group For Each Day

\begin{tabular}{|c|c|c|c|c|c|}
\hline Day & $\begin{array}{l}\text { Group I } \\
(\text { Mean } \pm \text { SD }) \\
\end{array}$ & & $\begin{array}{l}\text { Group II } \\
(\text { Mean } \pm \text { SD) }\end{array}$ & & $\begin{array}{l}\text { p } \\
\text { (CI 95\%) }\end{array}$ \\
\hline 1 & $\begin{array}{l}-88.9060 \\
0.01140\end{array}$ & \pm & $\begin{array}{l}-88.9160 \\
0.01140\end{array}$ & \pm & 0.203 \\
\hline 7 & $\begin{array}{l}-88.9060 \\
0.01140\end{array}$ & \pm & $\begin{array}{l}-88.9160 \\
0.01140\end{array}$ & \pm & 0.203 \\
\hline 14 & $\begin{array}{l}-88.9060 \\
0.01140\end{array}$ & \pm & $\begin{array}{l}-88.9160 \\
0.01140\end{array}$ & \pm & 0.203 \\
\hline 21 & $\begin{array}{l}-88.9060 \\
0.01140\end{array}$ & \pm & $\begin{array}{l}-88.9160 \\
0.01140\end{array}$ & \pm & 0.203 \\
\hline
\end{tabular}

\section{Discussion}

Lately, research on the role of amniotic membrane in regenerative medicine being actively carried out. Karaman et al $(2013)^{4}$ on the study said that the amniotic membrane is avascular membrane composed of epithelial cells and mesodermal tissue, which can reduce the potential proinflammatory cytokines. Besides being used in regenerative medicine, amniotic membrane has also been widely used as antiinflammatory effect on eye surgery, treatment of burns, surgery and wound closure. Amniotic membrane is also believed to have a low potential for adverse reactions. Tsai et al $(2004)^{8}$ on the study said that only human amniotic membrane-derived mesenchymal stem cells that do not express molecules of major histocompatibility complex class I (MHC I). Maybe this is the cause of immunological tolerance is high. ${ }^{8}$

Forbes $\mathbf{J}$ and Fetterolf DEC (2012) ${ }^{9}$ examines the use of amniotic membrane in the treatment of wounds and give good results. Roosenlbum B (2014) ${ }^{10}$ investigated the use of amniotic membrane allograft in diabetic ulcers no lower extremities. 5 ulcers from 3 patients were treated using amniotic membrane allograft after debridement, and the result is all wounds improved in the time range that is different. ${ }^{10}$

Neural Regeneration Research Board ${ }^{11}$, USA has done some research on amniotic membrane. In one study the research agency said that the amniotic membrane epithelial cells expressing neuronal phenotypes (microtubule-associated protein-2, glial fibrillary acidic protein and nestin). Conditioned medium from human amniotic epithelial cells can trigger the growth and proliferation of rat glial cell cultures in vitro. Whereas in other studies the body of research proves the transformation of human amniotic epithelial cells into neuron-like cells in the microenvironment of head injury, in vivo and in vitro. ${ }^{11}$ Karatman et al $(2013)^{4}$ 
showed that the amniotic membrane can help restore nerve injury fascialis.

The different results obtained in this study. Evaluation for 21 days showed no improvement in the group given amniotic membrane. This shows that within three weeks of the amniotic membrane has not proven to help restore the function of $n$. ischiadicus who suffered injury.

\section{Conclusion}

Limitations of this study is the evaluation of a short time, ie 3 weeks. Further studies with a longer time frame is needed to look at the role of amniotic membrane in the regeneration of peripheral nerve injury. Evaluation by other methods are also needed to get a more valid data. In addition to the evaluation function, the evaluation of nerve regeneration can also be done by making preparations for histopathology $y^{4,12}$; electrophysiological evaluation, histomorfometri, ${ }^{13,14}$, or by measuring ankle angle ${ }^{6}$. The combination of several methods of evaluation will produce data that is more valid and reliable.

\section{References}

[1] Sondell M, Lundborg G, Kanje M. Regeneration of the rat sciatic nerve into allografts made acellular through chemieal extraction. Brain Res., 795(1-2) :44-54, 1998.

[2] Zhang Y, Zhang Gm Liu Q, Wang Y. Effect of amnion-wrapped allogenic nerve bridging on peripheral nerve injury. Int. J. Morphol., 31(3) :980-985, 2013.

[3] de Albornoz PM, Delgado PJ, Forriol F, Maffulli N. Non-surgical therapies for peripheral nerve injury. $\mathrm{Br} \quad \mathrm{Med}$ Bull. 2011;100:73-100

[4] Takahiro Nakamura, Makoto Yoshitani, $\underline{\text { Helen }}$ Rigby, Nigel J. Fullwood, Wakana Ito, Tsutomu Inatomi, et al. Sterilized, freeze-dried amniotic membrane: a useful substrate for ocular surface reconstruction. Invest Ophthalmol Vis Sci. 2004 Jan;45(1):93-9.

[5] Karaman M, Tuncel A, Sheidaei S, et al. Amniotic membrane covering for facial nerve repair. Neural Regeneration Research. 2013;8(11):975-982. doi:10.3969/j.issn.16735374.2013.11.002.
[6] Sarikcioglu L, Demirel BM. Walking track analysis: an assessment method for functional recovery after sciatic nerve Injury in the rat. Folia Morphol. 2008; 68:1-7

[7] de Medinaceli L, Freed WJ, Wyatt RJ (1982) An index of the functional condition of rat sciatic nerve based on measurements made from walking tracks. Exp Neurol, 77: 634-643.

[8] Tsai MS, Lee JL, Chang YJ, Hwang SM. Isolation of human multipotent mesenchymal stem cells from second-trimester amniotic fluid using a novel two-stage culture protocol. Hum Reprod. 2004;19(6):1450-1456.

[9] Forbes J, Fetterolf DE. Dehydrated amniotic membrane allografts for the treatment of chronic wounds: a case series. Journal of wound care. 2012; 21:6

[10] Roosenblum B. Evaluation of a Human Amniotic Membrane Allograft (AMNIOEXCEL®) for Treating Challenging Diabetic Lower Extremity Ulcers. Dermascience. (2014) 1-8

[11] Li Zhi, Qin Hanjiao, Feng Zishan, Liu Wei, Zhou Ye, Yang Lifeng, et al. Human umbilical cord mesenchymal stem cell- loaded amniotic membrane for the repair of radial nerve injury. Neural Regen Res. (2013); 8(36):3441-3448

[12] Breshah M N, Sadakah AA, Eldrieny EA, Saad KA. Functional and histological evaluation of rat sciatic nerve anastomosis using cyanoacrylate and fibrin glue. Tanta Dental Journal: 10 (2013) 67 e 74.

[13] Dellon, A. L. and Mackinnon, S. E. (1989), Sciatic nerve regeneration in the rat. Validity of walking track assessment in the presence of chronic contractures. Microsurgery, 10: 220225. doi: 10.1002/micr.1920100316

[14] Hadlock TA, Koka R. Quantification of functional recovery following rat sciatic nerve transection. Exp Neurol. 2001;168(1):192-5. 